\title{
THE TRIUMPH OF LOVE AND ITS FAR REACHING CONSEQUENCES
}

\author{
Ma. de los Ángeles Castro H.
}

\begin{abstract}
RESUMEN
Robert Browning (1812-1889) enfoca en su monólogo dramático "An Epistle" el tema de la encarnación, fusión materia-espíritu y sus consecuencias multiformes. Este poema da pie al argumento de que entre Lázaro y Karshish y entre Karshih y Abid se genera una confrontación entre lo que el último en cada uno de esos pares siente con su corazón y lo que entiende con su mente. Pero la experiencia, el testimonio, vence al escepticismo con el amor que fluye de su propio centro, Cristo, hacia Lázaro, luego a Karshish, probablemente a Abid y eventualmente al lector de esta carta. El autor resalta así el triunfo del amor y sus profundas consecuencias en la experiencia humana.

Palabras clave: Robert Browning, "An epistle”, periodo victoriano, monólogo dramático.
\end{abstract}

\begin{abstract}
Robert Browning (1812-1889) summarizes in his dramatic monologue "An Epistle" his treatment of the subject of incarnation with its multiform consequences. This theme reveals how the spirit is embodied in matter. The poem gives way to the argument that between Lazarus and Karshish, first, and Karshish and Abid later the deed of Lazarus' resurrection gives way to creative tensions in regard to what the latter in each pair feels with his heart and understands with his mind. But experience overpowers any scepticism with love flowing abundantly outwards from its center, Christ, to Lazarus, then to Karshish, next to Abid, and eventually to the reader of this letter showing in this way how love operates as well as its far reaching consequences.
\end{abstract}

Key words: Robert Browning, “An Epistle”, Victorian period, dramatic monologue.

To Barbara Richter, Ph.D., with gratitude

Robert Browning (1812-1889) is an English writer from the Victorian period (18321901) who has been considered to be the master of the dramatic monologue (Smalley 1956: xxv). In 1855, he came out with Men and Women, a collection of poems where he displayed "his free power and scope in handling" this poetic instrument so peculiarly his own (Smalley 1956: xxiii). Browning's poem "An Epistle" is part of this collection. In it, he deals with a special moment in the life of an Arab physician called Karshish of the First Century A.D. "An

M.A. María de los Ángeles Castro Hidalgo. Escuela de Lenguas Modernas, Universidad de Costa Rica. San Pedro, San José, Costa Rica. 
Epistle" describes the moment when this man encounters for the first time the idea of a God of Love, a God incarnated in human form. Karshish has always been fascinated by the secrets of life, but being a medical man he has concentrated on matter. At the point he is writing this letter, we discover that he has come face to face with the secrets of the spirit, something that he feels both repelled and attracted by. Abid has been his friend and his teacher, and to him he writes while going to Jerusalem. To him he tells about his sufferings, medical discoveries, and this strange encounter with Lazarus, a man who " ... was dead and then restored to life / By a Nazarene physician of his tribe" (11. 99-100). "An Epistle" well helps Browning treat the subject of incarnation with its multiform consequences. This theme reveals how the spirit of love is embodied in matter, a theme appropriate for Browning for he was a writer who among many things was certainly characterized by "his zest for life in its concrete detail" (Smalley 1956: xiii). In this letter, then, he outlines the way love operates and its far reaching consequences in life as it interacts with matter, interaction that in turn leaves no room to a statement such as that given by Guerin on this poem, that it is not dramatic (1975: 132). On the contrary, this article proves the dramatic energy displayed in this piece on incarnation as love passes outward to reach life. And this is what happens in its most striking case, that of Lazarus, as love flows right from its center, Christ, first to Lazarus; then, from the latter to Karshish, next, hopefully to Abid and to eventual readers of this letter. The key in any case is to leave behind the gap between what the mind can understand and what the heart can feel for experience in this case overpowers scepticism.

"An Epistle" is a long letter something that Smalley finds to be typical of Browning for long letters were the frame he created for his heroes with a purpose in mind, "... to reveal their hidden purposes and to justify their decisions" (1956: xvi). Karshish writes from Bethany, a town a short distance from Jerusalem, where apparently Abib lives (11. 34-38, 51$53,1.301)$. The letter begins with a greeting that reveals something of both himself and his friend (11.1-20). For example, he is "Karshish, the picker of learning's crumbs / The not-incurious in God's handiwork" (11. 1-2); and the auditor is his admired teacher and friend Abid identified as being, "all-sagacious in our art, / Breeder in me of what poor skill I boast" (11. 7-8). His trip from Jericho to Bethany was rewarding for during it he acquired knowledge. He goes into detail about the impression Lazarus made upon his mind and his feelings. Next he explains that he cannot interview the wise man who performed this cure because he was killed. Lazarus, on the other hand, is completely sure that he was cured (in human form) by God himself. Then, Karshish tells about the events that led up to his meeting with Lazarus and tries to explain his own interest in the incident. He ends the letter to Abib with his own version of the message of love implicit in the incredible story. He imagines the voice of God addressing the soul of man, telling it that He too loves as does the human heart, that man finds his own identity in the image of his own face that he sees in the face of God, a God he can envision when love is doing its work.

It is a fact that in the poem's seven sections, Browning shows his interest in the theme of incarnation. This theme reveals that the spirit of love is present in matter, that it coexists in the physical universe. At the same time, each section of the poem reinforces the way in which the spirit portrays itself into matter. For example, in the first stanza Karshish sends his greetings and warm appreciation to his teacher. He calls him "breeder in me of what poor skill I boast" (L. 8). The letter, then, is both an expression of love and a symbol of the expansive nature of this spiritual force. When Karshish talks about his interest in the acquisition of knowledge, the reader becomes aware that he is humble and unselfish. His knowledge will 
serve others, and this is too a manifestation of love. He is a dedicated doctor and an honest, benevolent man, ways in which love reaches out life.

Karshish can be seen as a symbol of incarnation prior to Christianity. At this moment when the poem opens, he is facing Christianity, a religious and cultural aid to what he already is, by natural virtue. For instance, in the third section, he describes his great desire to tell his old master the unusual incident that he experienced. This shows that he wants to share, and that he wants to understand. Sharing and understanding are forms of love. In them, spirit becomes matter, that is, it takes on physical form. This desire Karshish has to share and to understand is put into words, a material form that also encloses spirit. The point with him is that he is aware of his thinking, of that he can test with his senses, but not of his capacity to feel and believe in things that belong to that world of emotions, of intuition and faith and that man can not scientifically prove.

The meeting with Lazarus is the center of the poem. Lazarus has felt the power and benevolence of God's work within himself. In that way, he is a man who has experienced eternity and infinity. This in turn implies that nothing can be the same for him. He seems to be a healthy man at the age of fifty. His body has been purified by the miracle he underwent, and Karshish describes him in such a way that it seems it is going to take time for that body to die again. Lazarus knows heaven, but he is presently confined to earth (11. 141-2). Thus, his friends think he is ill and take him to a doctor. Karshish sees him and tries to explain the case (11.79-96), but Lazarus's case stays long in his mind. Lazarus does not seem to bother about the opinion of others; his most important qualities have become easily visible - his patience and his meekness, qualities that further demonstrate the triumph of love and its far reaching consequences in life as Karshish's own deeply-felt and long-kept amazement confirms.

The fifth section reveals through Karshish how spirit becomes one with matter in man; in this case, it happens naturally, without his knowledge or will. As he discusses the death of Christ (11. 248-50, 256-9), he demonstrates his understanding of and even patience with human psychology. He is a doctor and feels that as such he is subject to the same risks Christ ran. He is not only a scientist letting reason do its work by itself; he emerges as a sensitive, highly intelligent observer who loves truth and beauty as well as his reaction to the flowers beside the pool suggests. His heart responds to such a sight not his head (11. 227-231). And God, or good, is already working likewise in him even without his awareness that this is so. The beauty of the flower may well resemble the beauty of the faith he has seen in Lazarus That beauty overpowers his heart in such a way that the letter itself with its length and details about the miracle and its effects on Lazarus, a life full of God's spirit, may well suggest.

The consequences of incarnation that is to say love, in this poem are varied. Christ, loving Lazarus, raised him from the dead. Lazarus, loving God, waits much as a lamb for God's will, "He will live, nay, it pleaseth him to live / So long as God please, and just how God please." (11. 209-210). Karshish, loving knowledge, marvels at what his mind rejects, compelled in spite of himself by it, and shares it with his friend. He is compelled by the attitude of faith that Lazarus displays. The man is thought ill by the others; Karshish can find no explanation for Lazarus return to life, but what is evident is that Lazarus is different from others. Karshish suggests that the man's condition is the result of imagination; that something evil broke out of his body leaving it healthy but "flinging ... life's gates too wide, making a clear house of it too suddenly" (11. 87-88). But what is true is that Lazarus' resurrection stays with him long and without a logical explanation. 
Loves bears its fruit in life, as Lazarus testifies through his actions, his behavior. Three times is Lazarus indirectly compared to Christ, as when he is called a "sheep", "lamb", "child": "Lead in their friend, obedient as a sheep," (1. 119); "Thus is the man as harmless as a lamb; (1. 232): "This grown man eyes the world now like a child" (1. 117). The point in this case is that Lazarus has experienced perfection, and the others, even the honest, intelligent Karshish, have not- "Heaven opened to a soul while yet on earth, / Earth forced on a soul's use while seeing heaven" (11.137-8). He is out of step in an imperfect world. Perfection and his faith in God mean everything - "Indeed, the special marking of the man / Is prone submission to the heavenly will_-" (11. 201-2). Karshish depends on his intellect, yet his heart also functions though he is not completely aware of the fact. His letter to Abib is the means whereby the message of love spreads to that wise man, whom we are to believe or perhaps hope is more prepared to receive it. What we know of Abib, however, we know through Karshish's esteem for him. Karshish tells us that Abid has shared his knowledge with him and that he is ab "all sagacious" person (1. 7). The fact of the devotion of Karshish is a reflection of Abib's treatment of him; "Breeder in me of what poor skill I boast"(1. 8), statement that in turn shows how humble and grateful of his former teacher he is, something that could well happen without his own awareness. The effects of love then spread in the present case from Christ to Lazarus to Karshish_- "And awe indeed this man has touched me" (1. 288), and then apparently to Abib. It is thus by action that spirit becomes matter; and the force causing this movement is love itself.

Each of the individuals in this poem is destined to grow as a result of the encounter with the spirit, with love. This growth is coming from the heart not the head, “ ".. he loves both old and young," states Karshish about Lazarus, "Able and weak, affects the very brutes / And birds_how say I? Flowers of the field_" (1. 227-9). The impact of the encounter may create in each of these individuals a new world of possibility by putting each one more in contact with the laws of his own being. God manifested himself to Lazarus by means of the miracle of rebirth. Karshish himself needs a rebirth; he has lived in the sterile world of the intellect, the world of science, but this strange encounter has moved him to reach out beyond the categories of the mind into an organic whole, the world of feeling. Abib is physically absent but spiritually present at Bethany in the gratitude Karshish feels for him. The gift of learning has borne fruit: Karshish can share and has been brought to emotional life by that. Abib now may transfer the letter of his old pupil, a physical carrier of love, to the reader of the poem, certainly even without his awareness. The letter sent to him is not only his; it becomes also the letter of any of the eventual readers of this account of death and rebirth and of faith. In this way, love reaches out mankind, too.

The differences between Karshish and Lazarus are crucial to the dramatic action of the poem. Karshish is a forerunner of modern psychiatrists. He specializes, as he says, in the "pricks and cracks" that "befall the flesh through too much stress and strain."(1. 10). He thinks Lazarus's problem is of this sort. He is not aware that the problem is in himself; not having had an experience of eternity himself, Karshish can only observe the consequences of this man's resurrection from outside and explain it in the terminology he knows. Lazarus, who has had the experience, simply lives and loves, aware that the heart embraces all that the head knows, and more: "The spiritual life around the earthly life: / The law of that is known to him as this, / His heart and brain move there, his feet stay here" (11. 183-5). Through this free love of God, the harmony of the whole is still available to Karshish in the beauty, say, of the blue 
flowers he observes by the edge of the pool- "I noticed on the margin of a pool/ Blueflowering borage, the Aleppo sort,/ Aboundeth, very nitrous. It is strange." (1. 280-1). That is, love is at work in him even without his awareness that it is; love is manifested in this simple comment about life that is symbolically followed by a sentence he repeats over and over and speaks of the effect Lazarus has had on him, "It is strange" (1. 281).

The two men are different, then, basically because of this big difference in experience. One entered eternity and returned: "And oft the man's soul springs into his face / As if he saw again and heard again/ His sage that bade him "Rise" and he did rise." (11.191-3). The other one did not and can know it only by vague intuition. Still both operate under God's love. Lazarus's vision is unlimited; his means limited, as the following description reads, "Heaven opened to a soul while yet on earth / Earth forced on a soul's use while seeing Heaven" (11.140-1). The purity that Lazarus has within transcends and enriches the spirit of those around him; in that way, it can find its way out to the reader. Lazarus "knows God's secret while he holds the thread of life" (11. 211-12). Karshish's most moving tribute to him is that "he loves both old and young / Able and weak, affects the very brutes / And birds-how say I? Flowers of the field-as a wise workman recognizes tools / In a master's workshop, loving what they make" (11. 227-231). The idea seems to be, using Ponder's words, "not to wonder how love works, but just to dare to begin releasing it, from within yourself. When you do, you will always witness interesting and satisfying results" (1966: 15). Such is the case with the experience here presented. Lazarus's love compels incipient love in Karshish. And at the close of the letter, he is right where the message of love can begin to function within him. His admiration, thrown, even without his consent, from within, goes beyond his reason- "The very God! Think, Abid; dost thou think?/ So, the All-Great, were the All-Loving too__" (11. 304-5).

Karshish's reactions are due to Lazarus' own testimony, to the way he acts in life. It is important that Lazarus is not aggressive, does not seek to make converts. He believes and trusts in the power of God. He knows God's secret is the secret of love. He respects what Karshish most respects, the sphere of the mind. Yet he comprehends more than the mind. Karshish understands that Lazarus is "no fool" (1. 124). The tension arises from the impossibility on the part of Karshish to rationalize the behavior of a man" harmless as a lamb" (1. 232), "obedient as a sheep" (1. 118), able even to die again "patient to the last for that same death" (1. 205-6), fearless in the face of an advancing army that Karshish tells him could destroy "thy town, thy tribe, thy crazy tale / and thee all at once" (11. 123-4). The rebuke "Beast" (1. 221) is nothing to him. He sees heaven, he gazes rapt at the littleness of any trifling fact, for in it there is for him "prodigious import, whole results" (1. 152). Lazarus loves all. Karshish cannot explain that with the devices of his intellect. Karshish's amazement kept till the end may be the beginning of new love on his part: "But love I gave thee, with myself to love, / And thou must love me who have died for thee! / The madman saith He said so: It is strange" (1. 310-12). That is the striking message that reaches him, the message of love of Christ himself that leads him end up with a sentence that so well depicts that difference between what man can understand with the mind and what he can grasp with his heart.

The impact Karshish may have upon Abib is one less, perhaps, of difference in nature than difference in time, space, and experiences. The two are alike in important ways. Both are doctors, they have been boys together (11. 170-1); both share; they seem to be humble, generous, intelligent men. Both are interested in life and the soul. But they are separated by time, space, and here by an important experience Karshish has had. The possible effects in this case, in 
distinction to those of the previous two relationships discussed, are largely implicit. The reader himself must grasp it from Browning's arrangement of the poetic materials. Does Abib receive the message of love? Does he transfer it? These questions can only be answered by the reader of the poem. What Abid does in his own fictional life is not the main question, though. What is more important is that he has already become a possible part of each reader's life, a carrier of God like the "prodigious armaments" (1. 146) and even the "mule with gourds" (1. 148). To Lazarus these things are equally perfect. They are aspects of the workmanship of God, "tools in a master's workshop" (11. 229-30), meant to be admired, loved. Thus, the reader could find in the teacher's reception of his student's adventure another demonstration of the far-reaching effects of love in life. Abib, the Arab wise man, serves his maker like Lazarus, the Jewish workman, as the Maker desires, unintentionally may be said, but he does so. The reader could identify with either one of the three: with Lazarus, with Karshish, or with Abid. If at the end he understands the lesson of love, it makes no difference and it is equally valid. Like Lazarus, he can fold his hands, "watching the flies that buzzed" (1. 124). He is himself. This is why a statement such as Guerin's in this case, then, that the poem is not dramatic (1975: 132) is not pertinent for there is a constant interplay of energy, of action and interaction among those involved in the account, including the reader as he or she contemplates these characters, and the possibility of birth or rebirth of spirit in life.

Browning's poem can direct a man's understanding of his own experience for Lazarus, Karshish, Abib are like models for the imagination, the heart, and the will. This poem can guide the mind and can move the heart. Action arises in many ways out of perception, but the great beauty of love is that it never forces; it leaves the individual spirit free. The culmination of Browning's effort in this poem is certainly left to the individual involved. Browning held that "the poet's function is to give the reader portrayals of life and to fill them with such vitality that the reader would be stimulated by them to work out conclusions regarding their meaning for himself" (Smalley 1956: xx)— statement that fits what this poem is supposed to do. Browning does help the reader move from the abstract, love, for example, to the concrete, say resurrection. That is the case with the soul, too, depicted here as "that puff of vapor from his (God's) mouth" (1. 6), "the wily vapor"(1. 11), a "fume" (1. 103); love itself becomes concrete in myriad ways. But perhaps the poem is most adequately summarized in Karshish's invention, the words he puts into God's mouth: "Face, my hands fashioned, see it in myself" (11. 3-8). That is, man must find his own face in the face of God. The effect of Lazarus upon Karshish finds a concrete shape; it creates this dramatically experienced abstraction: man is, this Arab doctor seems to be saying, what he finds in the face of God, of that Christ Himself who more than willingly raised the dead Lazarus, that reaches matter and changes it for the better. And this indeed is a humbling, exalting thought for the Christian world that year after year, for more than twenty centuries now, with noise, joy and light celebrates the birth of Christ in the midst of mankind-the incarnation of LOVE in life. He left his deeds and message without forcing them upon no one but letting His own light flow through forever in the account of what he said and did. Like one of His good disciples, Browning picks and fuses artistically and optimistically through Lazarus's own testimony in "An Epistle," the far reaching effects of a personal encounter with the spirit, with God through Jesus Himself here in life. 


\section{Bibliography}

Abrams, M. H. et al. (eds.). 1968. The Norton Anthology of English Literature. Vol. 2. New York: W. Norton \&.Company. 727-745.

Faverty, Frederic (ed.). 1956. The Victorian Poets: A Guide to Research. Cambridge: Harvard Univ. Press.

Guerin, Wilfred. 1975. "Irony and Tension in Browning's Karshish.” Victorian Poetry. I: 132139.

Miller, Hillis. 1963. The Disappearance of God. Cambridge: Harvard University.

Ponder, Catherine. 1966. The Prospering Power of Love. Missouri: Unity Books.

Smalley, Donald (ed.). 1956. Poems of Robert Browning. Boston: Mifflin Company.

Otto, Rudolf. 1967. The Idea of the Holy. London: Oxford University Press. 